\title{
Ethnic elements in the application of the costume design
}

\author{
Guohui Wu $\mathrm{W}^{1, \mathrm{a}}$ \\ ${ }^{1}$ Jiangxi Institute of Fashion Technology, Jiangxi, Nanchang, 330201 \\ a78865425@qq.com
}

Keywords: National elements; Clothing design; Aesthetic; application

\begin{abstract}
With the gradual development of the modern aesthetic, ethnic elements in the clothing design more and more get the attention of consumers, national wind has become a unique style of dress. Modern clothing design through the selection of traditional Chinese national elements and the fusion of modern technology, realize to inherit and carry forward traditional national process. At the same time, the traditional pattern, style, modelling, the element such as the craft technique through deformation and reconstructed into design, provide a new way of thinking on modern dress design. This paper introduces the application of the national element in modern clothing design and analysis of national element in modern clothing design, and the significance of People's Daily lives, trying to grasp the right degree between modern and traditional provide solution, using the national element to add ideas and aesthetic feeling for modern dress design.
\end{abstract}

\section{The introduction}

Ethnic elements is an external form, but also contains the national long-term development in the process of the connotation of national culture, contains many of the nation in the world, and formed a brilliant diversity of national culture and elements. National elements not only show the clothing in the clothing design, decoration, fabric and styling, but also contains the clothing contains national culture connotation. The ethnic groups of China's national number, costume culture, distinctive traditional national elements and the rich. To use these elements to the design of modern dress, not only inherited the traditional ethnic culture is absorbed, and the great innovation of modern clothing designs. For the flexible use of the national factors not only greatly enriched the People's Daily life culture and aesthetic experience, but also can effectively achieve the effective inheritance and development of traditional dress.

\section{The composition analysis of national element}

Due to the various nationalities in the long-term production and labor of the regional differences in the process, the dress also embodies the different regional differences in life style, the difference with different geographical and cultural national habits and customs, religious beliefs, and many other factors. Through the study of China's ethnic costumes, ethnic factors mainly embodied through the following aspects. Materials, design, colour is applied, and of the clothing production process is the basic aspects of a national element. National costumes of the applications of the materials also embody the local climate conditions on the trace of the people affected, in ancient times also formed the "south to north skirt gown", the south skirt and sweater design usually adopt the material permeability of silk and silk etc., and the north, especially in the northwest region, due to differences in climate conditions, in order to meet the requirements of warm and cold, such as fur material is a significant application.

In costume material application, the traditional Chinese silk number and variety is numerous, formed to regional features of different kinds, brocade, preface, brocade, etc., regardless of their geographic fur clothing material is widely used in the local, local resistance to the cold climate conditions, also formed a kind of primitive and wild sense of beauty.

Has the national characteristics of clothing design is the important experience of national elements, in the traditional Chinese pattern design and application, the influence of economic level and people's cultural concept, many plants and animals, such as text, totem, landscape become common decorative patterns of clothing. Ancient people by imagining to exaggeration and distortion, the 
group has formed unique national dress patterns.

Application of color in the national elements is an important part of the national culture. Part of the national style of clothing with colorful, and some national costumes on the application of color according to the characters' social status and identity has the strict limit, the choice of this kind of colour has applied in clothing design in the national culture characteristics.

Ethnic process embodies the ancient people's labor skills, different nationalities but also become an important element with labor mark of national costumes, ethnic clothing technology on modern dress design still has very important significance. These tie-dye, embroidery, drawnwork, batik process not only has a wide range of USES. And embodies the characteristic of national technology.

\section{Clothing to join in the design of the method and application significance of national element}

Ethnic elements application in the clothing design makes the modern clothing designers find new inspiration and train of thought, the use of the national elements also received more significant results. Through flexible transformation of national elements and apply, national elements with the popular elements of The Times, gradually formed the more consumers favorite kind of clothing style.

Application more successful in this industry with foreign designer Tom ford and Robert cavalli and so on, they study through to the traditional Chinese qipao, includes the application of the shape and material of elements in the design of their performance. Domestic based on the research of the traditional culture, the use of different ethnic customs new accessories to attract many consumers' eyes. Material popular "inset jades" adorn article, with the Angle of the Mongolian unique decoration, with amorous feelings of the miao nationality silver and so on national element has been widely used in modern dress.

Vast area in our country, the traditional national culture element contains the rich, these national elements are extracted and development to meet the increasing of people's aesthetic demand, at the same time to improve the overall level of our country dress design major help. Traditional clothing processing technology and traditional factors such as design can be inherited in the process and the new development, for the rich people's spiritual life, excavate the potential of traditional culture has played a role.

Current Chinese costume design industry market development is still in its infancy, there is insufficient design fashion sense in clothing design, variety characteristics of single application in national elements in the technique is relatively rigid, cannot achieve together with fashion trends, application effect is not ideal. International dress brand occupy a larger share in the national clothing consumption, national costumes of ethnic elements is less, can't meet the demand of the increasing of people's aesthetic.

\section{National element clothing design direction}

National element clothing design direction. Problems need to pay attention to in the application of national elements For national elements application should achieve and fashion fusion, form a more harmonious effect. National elements application should be for the design of modern clothing glory, in the clothing structure, the use of local grain and the collocation of color reflect national factors, costume design, if out of the combination of fashion and national factors clothing market will shrink. Modern clothing consumption crowd is mainly young people to the group, so in the clothing design should consider the audience psychology and accept ability, national elements should be used effectively for deformation and innovation to adapt to the modern's aesthetic psychology and aesthetic taste.

National elements and form style design, costume design process, mastery of national elements can't take the way of curt added, considering the overall design theme and style of the dress, to incorporate ethnic factors. In the design process can not for the ethnic factors in the design of a large amount of added to cause the destruction of the whole style of dress design, the design of the formation of neither fish nor fowl.

Clothing design towards the folk elements. In under the influence of modern pay attention to 
the trend of clothing design presents the diversified development trend, many designers design inspiration from the ethnic costumes, formed a large number of clothing design. The future will further deepen the development trend of diversification and individuation, in the face of the impact of the international brand of pop culture, how to keep the national culture in open cultural exchange, retention and succession of national elements effectively become the urgent task of modern clothing design.

In clothing design, the use of national factors should break through the application of specific national element, traditional ethnic patterns, and has gradually not adapted to the aesthetic needs of modern society, therefore in the process of the use of the national elements, will be out of the representational form, form the new symbol of national elements. To innovation of design concept, seize the national elements of inner spirit, the spirit of the traditional connotation into the modern design.

The era of national elements of clothing design and internationalization. The more national, the more of the world. National costumes, as a carrier of traditional culture, is the crystallization of the wisdom of national culture, is people's identity and cultural identity of important link. Under the environment of new era, the national elements of clothing design gradually toward internationalization plays an important role in the establishment of national self-confidence, for the performance characteristics of national culture, rich dress culture of the whole international has a very important role. 's national costumes, as a kind of culture, in a combination of modern and fashionable element, through the creation of fusion designers will be able to get a more broad space for development.

\section{Conclusion}

Under the background of the present world, how to make the national elements to obtain the very good inheritance and development of our country, is the important issue. Ethnic elements include many elements, not just in our country traditional dress of color, pattern and different shapes, so be careful studies our country traditional culture embodied the spirit and connotation, and follow the current trend, and created again, realize marketization development, so that it can make the connotation of national culture reflected in people's spiritual life in penetration, our country has a lot of national elements, costumes of ethnic elements, their performance and technique is different, need according to different analysis, promote its development.

Integrated into the national elements of clothing design makes the traditional ethnic culture with the new vitality, the international environment determines the with innovation design idea of national culture will become the direction of future development, is the important basis of national vitality and personality, therefore, update the design idea, draw national elements and innovation is the modern dress design must face the problem..

\section{Reference}

[1] Feng Xiao ran. National costumes popular influence [J]. Journal of chemical fiber and textile technology, 2012 (02).

[2] mountains. Enhancing competitiveness of modern costume design [J]. Market modernization, 2010 (16).

[3] JiDeJin. The application of Chinese traditional pattern in modern fashion design [J]. Journal of tianjin academy of fine arts, 2012 (04).

[4] xiao-bo wu. The application of the national costume elements in modern fashion design study

[J]. Journal of tianjin textile science and technology, 2012 (04).

[5] Chen jia yi costume elements application in modern fashion design [J]. Journal of stage, 2013 (6). 